\title{
Effect of post-mortem time on post-thaw characteristics of Spanish ibex (Capra pyrenaica) spermatozoa
}

\author{
M.R. Fernández-Santos ${ }^{\mathrm{a}, \mathrm{b}, *}$, A.J. Soler ${ }^{\mathrm{a}}$, M. Ramón ${ }^{\mathrm{a}}$, J.L. Ros-Santaella ${ }^{\mathrm{a}}$, \\ A. Maroto-Morales ${ }^{a}$, O. García-Álvarez ${ }^{c}$, A. Bisbal ${ }^{a}$, J.J. Garde ${ }^{a}$, M.A. Coloma ${ }^{d}$, \\ J. Santiago-Moreno ${ }^{\mathrm{d}}$ \\ a Biology of Reproduction Group (IREC), UCLM-CSIC-JCCM, Albacete, Spain \\ b Regional Development Institute (IDR), UCLM, Albacete, Spain \\ c CERSYRA (JCCM), Valdepeñas, Spain \\ d Department of Animal Reproduction, INIA, Madrid, Spain
}

\section{A R T I C L E I N F O}

\section{Article history:}

Received 28 April 2011

Received in revised form

19 September 2011

Accepted 24 September 2011

Available online xxx

\section{Keywords:}

Spanish ibex

Fertility

Post-mortem time

Mitochondrial status

DNA stability

\begin{abstract}
A B S T R A C T
Viable epididymal sperm can be obtained in the Spanish ibex during $24 \mathrm{~h}$ after death, but it has been observed a significant effect of the post-mortem time on fertility success, so only goats inseminated with semen recovery during the first $8 \mathrm{~h}$ became pregnant. The aim of this study was to determine the effect of post-mortem time on epididymal semen samples from of Spanish ibex. For this purpose, sperm samples from 36 males were collected at different post-mortem times, from 2 to $24 \mathrm{~h}$, and cryopreserved. Thawed samples were incubated for $2 \mathrm{~h}$ at $37^{\circ} \mathrm{C}$ without dilution or after dilution in a modified Tyrode medium, in order to study the sperm resistance to dilution. Moreover, flow cytometry was used to assess the sperm viability (PI), phospolipid disorder of the plasma membrane (M540), mitochondrial membrane potential (Mitotracker Deep Red), indirect apoptosis markers (YOPRO-1) and sperm chromatin stability $\left(\mathrm{SCSA}^{\circledR}\right)$. Sperm motility was evaluated by computer-assisted sperm analysis (CASA). Our results have shown that post-mortem time caused a reduction in mitochondrial membrane potential. In this regard, the loss of energy could be responsible for the loss of maintenance of the membrane with a consequent increase in permeability leading to a decrease in sperm viability and motility, losing linearity and speed. Moreover, the loss of maintenance of the membrane influence the extent to which sperm will survive the cryopreservation process, as it shows the results obtained from the dilution-incubation resistance test. Finally, one important finding of this study is the demonstration of no effect of post-mortem time on post-thaw DNA integrity, giving us the possibility of using sperm samples from valuable males, even if it was not possible to process during the first $8 \mathrm{~h}$.
\end{abstract}

(c) 2011 Elsevier B.V. All rights reserved.

\section{Introduction}

The present study arises from a previous work by Santiago-Moreno et al. (2006) which showed that the effect

\footnotetext{
* Corresponding author at: Grupo de Biología de la Reproducción, IREC, Campus Universitario, sn, 02071, Albacete, Spain. Tel.: +34 967 599200; fax: +34 967599238.

E-mail address: MRocio.Fernandez@uclm.es (M.R. Fernández-Santos).
}

of the time elapsed from animal death to semen collection (hereafter post-mortem time) affected the sperm Spanish ibex quality, significantly, and that only goats inseminated with thawed sperm recovered within $8 \mathrm{~h}$ after death became pregnant.

Viable epididymal spermatozoa can be retrieved from dead animals (Comizzoli et al., 2001; Fernandez-Santos et al., 2007a). The main problem for the post-mortem recovery of spermatozoa is the rapid degeneration after death (Wildt, 2000). A number of studies in mice (Sankai 
et al., 2001), boar (Kikuchi et al., 1998), dog (Yu and Leibo, 2002), some African wild ruminant species (Friedmann et al., 2000; Killian et al., 2000), mouflon (Garde et al., 1995), and red deer (Martínez-Pastor et al., 2005; Garde et al., 2006; Fernandez-Santos et al., 2007b, 2009a) have been conducted to determine the quality decay of epididymal spermatozoa recovered post-mortem. Storing the testicles instead of collecting the sperm sample is a common strategy when it is not possible to freeze the sample immediately.

Recent advances in our ability to understand and manipulate the fundamental mechanisms regulating sperm function have led to the development of a new generation of diagnostic techniques (i.e. resistance tests and flow cytometry), designed to yield objective data on the functional characteristics of spermatozoa (Rodríguez-Martínez and Barth, 2007). In this regard, we have incorporated new functional sperm tests to further explore the effects of the post-mortem time on the sperm quality of the epididymal frozen-thawed semen in the Spanish ibex in order to explain low fertilities. On one hand, thawed sperm samples were subjected to a dilution-incubation stressful situation (dilution in Tyrode medium). Incubation in Tyrode has been demonstrated as a resistance test to sperm dilution (Garde et al., 2003; Soler et al., 2003a), since resistance to dilution is very important at the time of fertilization. On the other hand, we used flow cytometry as tool to the more in depth knowledge of functional sperm characteristics. It has been study together membrane integrity, apoptotic markers and mitochondrial status in spermatozoa as describe by Martinez-Pastor et al. (2008). Moreover, it has been also studied phospholipid disorder of the plasma membrane (Harrison et al., 1996).

To fully address this topic, we have evaluated sperm motility by a computer-assisted semen analyzer (CASA) which provide precise and accurate information on different sperm motion characteristics (Gravance and Davis, 1995), allowing a more accurate prediction of fertility than the parameters assessed by the routine microscopically semen evaluation (Farrell et al., 1998; Malo et al., 2005).

Finally, we carried out, for the first time, the study on the DNA integrity levels in the Spanish ibex epididymal spermatozoa using the test $\left(\mathrm{SCSA}^{\circledR}\right)$ (Evenson and Jost, 2000); this test has been used for fertility estimation, as well as detection of problems during spermatogenesis (Januskauskas and Rodriguez-Martinez, 1995). Specifically, we have studied the effect of post-mortem time on DNA integrity of Spanish ibex epididymal spermatozoa.The aim of the present study was therefore evaluate the effect of post-mortem time on postthaw sperm characteristics in order to know more in depth the mechanisms underlying the differences in fertility in the Spanish ibex, in the context of cryopreservation of ibex spermatozoa and the conservation of the species.

\section{Material and methods}

\subsection{Reagents and media}

Flow cytometry equipment, software and consumables were purchased from Beckman Coulter (Fullerton,
CA, USA). The rest of the chemicals (Reagent grade or higher) and the fluorescence probes propidium iodide (PI) and Merocyanine 540 (M540) were acquired from Sigma (Madrid, Spain). Both YO-PRO-1 and Mitotracker Deep Red were purchased from Invitrogen (Barcelona, Spain). Stock solutions of the fluorescence probes were: PI: $7.5 \mathrm{mM}$; YO-PRO-1: $50 \mu \mathrm{M}$; Mitotracker Deep Red: $1 \mathrm{mM}$; Merocyanine: $3.4 \mathrm{mM}$. All fluorescent stocks were prepared in DMSO and kept at $-20^{\circ} \mathrm{C}$ and in the dark until needed. The extender was prepared in the laboratory using reagentgrade chemicals purchased from Panreac Química S.A. (Barcelona, Spain) and Sigma Chemical Co. (St. Louis, Missouri, USA).

The freezing extender (TCG) was made up of Tris $313.7 \mathrm{mM}$, citric acid $114.5 \mathrm{mM}$, glucose $33.3 \mathrm{mM}$, 5\% glycerol $(\mathrm{v} / \mathrm{v})$ and $6 \%$ egg yolk (v/v) (Santiago-Moreno et al., 2004). This solution was adjusted to $\mathrm{pH} 7.0$ by the addition of $\mathrm{NaOH}$ at room temperature, and to an osmolarity of $345 \mathrm{mOsm} / \mathrm{kg}$ measured in the absence of glycerol.

Modified Tyrode medium was composed of: $120 \mathrm{mM}$ $\mathrm{NaCl}, 3.1 \mathrm{mM} \mathrm{KCl}, 2 \mathrm{mM} \mathrm{CaCl} 2,0.4 \mathrm{mM} \mathrm{MgSO}_{4}, 0.3 \mathrm{mM}$, $20 \mathrm{mM}$ HEPES, $21.7 \mathrm{mM}$ sodium lactate, $5 \mathrm{mM}$ glucose, $1 \mathrm{mM}$ sodium pyruvate, $50 \mu \mathrm{g} / \mathrm{mL}$ kanamicine, $20 \mu \mathrm{g} / \mathrm{mL}$ phenol red and $5 \mathrm{mg} / \mathrm{mL} \mathrm{BSA}$ (pH 7.5, $290 \mathrm{mOsm} / \mathrm{kg}$ ).

\subsection{Animals and sperm collection}

Testicles were obtained from 36 mature males (5-14 years of age) of Spanish ibex that were legally culled and hunted during the rutting season (November, December) in the Tejeda y Almijara National Game Reserve $\left(36^{\circ} \mathrm{N}\right.$ latitude, Málaga, Spain). The hour of death and the age were recorded in each animal. Ibex age was assessed by their horns (marks of growth) (Fandos, 1995). Testicles with their scrotal sac were transported to the laboratory immediately after removal. The collection of epididymal spermatozoa was done at different times after death (range: 2-24h). Ibexes live in high mountain areas with difficult access, especially in winter, and thus the recovery of testes after death may require a long time. In order to reduce the time elapsing between ibex death and sperm collection, we set up a small laboratory among the mountains of this Game Reserve. The testicles extracted were kept, during transport and during laboratory processing, at environmental temperature (about $12{ }^{\circ} \mathrm{C}$ in the experimental period).

For collection of the epididymal spermatozoa, testes and epididymides were removed from the scrotal sac. In a second step, cauda epididymides were isolated from testes and from surrounding connective tissue. The cauda epididymides were carefully cleaned with sterile dry gauze and then sperm were collected performing small longitudinal and transverse cuts with a surgical scalpel, and taking the white fluid emerging from the dissected tubules (Soler et al., 2003b).

\subsection{Sperm evaluation and preparation}

After spermatozoa collection, semen was diluted in an exact volume of $(1.0 \mathrm{~mL})$ the freezing media TCG. Then was assessed sperm concentration with a Neubauer chamber 
(Marienfeld, Lauda-Königshofen, Germany). In addition, sperm motility, acrosome status and plasma membrane integrity were assessed for each sample to determine sperm quality in vitro previously to cryopreservation.

\subsection{Cryopreservation of epididymal spermatozoa}

The epididymal spermatozoa were diluted immediately after collection in the freezing extender. The addition of media took place at room temperature $\left(22^{\circ} \mathrm{C}\right)$ and semen was diluted to a final sperm concentration of $800 \times 10^{6} \mathrm{sperm} / \mathrm{mL}$. After dilution, semen was placed in a $15 \mathrm{~mL}$ centrifuge tubes (FalconTM) and transferred to a refrigerator at $5^{\circ} \mathrm{C}$. Diluted semen remained $1 \mathrm{~h}$ until it reached $5^{\circ} \mathrm{C}$ and was kept at this temperature for $2 \mathrm{~h}$ longer for equilibration (total refrigeration time at $5^{\circ} \mathrm{C}, 3 \mathrm{~h}$ ). At this point, aliquots of semen were loaded into $0.25 \mathrm{~mL}$ French straws $\left(200 \times 10^{6}\right.$ spermatozoa per straw) and frozen by placing them directly into nitrogen vapours; $5 \mathrm{~cm}$ above the surface of the liquid nitrogen for $10 \mathrm{~min}$. Frozen semen was maintained into liquid nitrogen at $-196^{\circ} \mathrm{C}$ for 6 months and then thawed. Thawing was performed by dropping the straws in a water bath with $5 \mathrm{~L}$ of saline serum at $37^{\circ} \mathrm{C}$ for $30 \mathrm{~s}$, and the contents were poured into a glass tube.

Thawed samples were incubated at $37^{\circ} \mathrm{C}$ for $2 \mathrm{~h}$ without dilution (i.e., in the freezing diluent) or after dilution 1:25 in a modified Tyrode medium.

\subsection{Assessment of frozen-thawed spermatozoa}

Sperm motility and acrosomal status were assessed for each sample after thawing. For sperm motility (subjective) a 5- $\mu \mathrm{L}$ drop of the sample was put on a prewarmed slide, covered with a coverslip and examined under phasecontrast microscope with awarming stage at $37^{\circ} \mathrm{C}$ (Nikon (Kanagawa, Japan) Eclipse 80i; negative contrast optics). Percentage of individual motile sperm (motility) was noted. Acrosomal integrity was evaluated after a 1:20 dilution in $2 \%$ glutaraldehyde in $0.165 \mathrm{M}$ cacodylate $/ \mathrm{HCl}$ buffer (pH 7.3). The percentage of spermatozoa with intact acrosomes (\% NAR) was assessed by phase contrast microscopy at $\times 400$ and 100 cells from each sample were observed (Pursel et al., 1978).

\subsubsection{Sperm motility assessed by CASA}

A pre-warmed Makler counting chamber (10 $\mu$ m depth) was loaded with $5 \mathrm{~mL}$ of sample. The CASA system consisted of a triocular optical phase contrast microscope (Nikon Eclipse 80i; Nikon; Tokyo, Japan), equipped with a warming stage at $37^{\circ} \mathrm{C}$ and a Basler A302fs digital camera (Basler Vision Technologies, Ahrensburg, Germany). The camera was connected to a computer by an IEEE 1394 interface. Images were captured and analyzed using the Sperm Class Analyzer (SCA2002) software (Microptic S.L.; Barcelona, Spain). Sampling was carried out using a $\times 10$ negative phase contrast objective (no intermediate magnification). Image sequences were saved and analyzed afterwards. Software settings were adjusted to goat spermatozoa. The standard parameter settings were as follows: 25 frames/s; $20-90 \mu \mathrm{m}^{2}$ for head area; $\mathrm{VCL}>10 \mu \mathrm{m} / \mathrm{s}$ to classify a spermatozoon as motile. For each spermatozoa, the software rendered the percentage of motile spermatozoa, three velocity parameters (VCL: velocity according to the actual path; VSL: velocity according to the straight path; VAP: velocity according to the smoothed path), three track linearity parameters (LIN: linearity; STR: straightness: WOB: wobble), the ALH (amplitude of the lateral displacement of the sperm head), and the BCF (head beatcross frequency). In this paper, we have shown VCL, VAP, VSL and LIN results. These parameters have been defined elsewhere (Mortimer, 1997).

\subsubsection{Assessment of sperm viability and phospholipid disorder of the plasma membrane}

We assessed the state of plasma membrane with YOPRO-1 (Martinez-Pastor et al., 2008), the viability with propidium iodide (PI) (Martinez-Pastor et al., 2008) and the membrane fluidity with Merocyanine 540 (M540/YOPRO-1) (Harrison et al., 1996). M540 is believed to detect a decreased packaging order of phospholipids in the outer leaflet of the lipid bilayer of the plasma membrane by means of an increase in its orange fluorescence, which occurs, for instance, in capacitated spermatozoa (Kardive et al., 2009).

A staining solution using modified Tyrode was prepared by adding $50 \mathrm{nM}$ YO-PRO-1 (stock: $100 \mu \mathrm{M}$ in DMSO), $1 \mu \mathrm{M}$ M540 and $15 \mu \mathrm{M}$ PI (stock: $7.5 \mathrm{mM}$ in milli-Q water). We diluted $20 \mu \mathrm{L}$ of sample in $0.5 \mathrm{~mL}$ of staining solution in polypropylene tubes for flow cytometry. The tubes were allowed to rest for $15 \mathrm{~min}$ in the dark and then analyzed by flow cytometry.

\subsubsection{Assessment of mitochondrial membrane potential}

Mitochondrial membrane potential of the samples were evaluated with $0.1 \mu \mathrm{M}$ YO-PRO-1 and $100 \mathrm{nM}$ Mitotracker Deep Red solution (stock: $1 \mathrm{mM}$ in DMSO) in modified Tyrode. Mitotracker Deep Red (MT) is a far red-fluorescent dye (abs/em $\sim 640 / 662 \mathrm{~nm}$ ) that stains mitochondria in live cells and its accumulation is dependent upon membrane potential $\left(\Delta \psi_{\mathrm{m}}\right)$, sign of an active oxidative respiration, and consequently sequestered in the mitochondria. Sperm samples were diluted down to $10^{6}$ spermatozoa $/ \mathrm{mL}$, and $300 \mu \mathrm{L}$ were transferred to a polypropylene tube and let in the dark for $30 \mathrm{~min}$. After incubation, samples were run through the cytometer (Martinez-Pastor et al., 2008).

\subsubsection{Flow cytometer analyses}

After incubation times, sperm samples were analyzed using a Cytomics FC500 (Beckman coulter, Inc., USA). It was used one a $488 \mathrm{~nm}$ Argon-Ion laser for exciting YO-PRO-1, M540 and PI. A 638 LED laser was used for exciting MT. We acquired the FSC (forward-scatter light) and SSC (sidescatter light) signals plus the fluorescence light of each fluorochrome using four photodetectors. FL1 was used for YO-PRO-1 (530/28BP filter), FL2 for M540 (575/26BP filter), FL3 for PI (620SP filter) and FL4 for MT (670/40BP filter). The acquisition was controlled using the MXP software. All the parameters were read using logarithmic amplification. Spermatozoa were discriminate from debris within the events acquired. The filtered events were displayed in dot plot showing FL1/FL3 (YO-PRO-1 vs PI), FL2/FL1 (M540 
vs YO-PRO-1) and FL4/FL1 (MT vs YO-PRO-1). We acquired 5000 spermatozoa from each sample.

YO-PRO-1-/PI- were considered viable spermatozoa (indicating live spermatozoa with intact plasmalemma) and YO-PRO-1+/PI- as apoptotic-like membrane changes spermatozoa. It was also considered M540-/YO-PRO$1-$ as viable with intact plasmalemmna cells and M540+/YO-PRO-1 - were considered viable spermatozoa with high membrane phospholipid disorder. Finally, YOPRO-1-/MT+ population were considered as live with high $\Delta \psi_{\mathrm{m}}$ spermatozoa.

\subsubsection{Sperm chromatin assessment}

Chromatin stability was assessed following the SCSA (Sperm Chromatin Structure Assay), based on the susceptibility of sperm DNA to acid-induced denaturation in situ and on the subsequent staining with the metachromatic fluorescent dye acridine orange (Evenson and Jost, 2000). Acridine orange (AO) fluorescence shifts from green (dsDNA; double strand) to red (ssDNA; single strand) depending on the degree of DNA denaturation. Samples were diluted in TNE buffer $(0.01 \mathrm{M}$ Tris- $\mathrm{HCl}, 0.15 \mathrm{M} \mathrm{NaCl}$, $1 \mathrm{mM}$ EDTA, $\mathrm{pH} 7.4$ ) to a final sperm concentration of $2 \times 10^{6}$ cells $/ \mathrm{mL}$. Samples were frozen in liquid nitrogen and stored in an ultracold freezer at $-80^{\circ} \mathrm{C}$ until needed. For analysis, the samples were thawed on crushed ice. Acid-induced denaturation of DNA in situ was achieved by adding $0.4 \mathrm{~mL}$ of an acid-detergent solution $(0.17 \%$ Triton $\mathrm{X}-100,0.15 \mathrm{M} \mathrm{NaCl}, 0.08 \mathrm{~N} \mathrm{HCl}, \mathrm{pH} 1.4)$ to $200 \mu \mathrm{L}$ of sample. After $30 \mathrm{~s}$, the cells were stained by adding $1.2 \mathrm{~mL}$ of an acridine orange solution ( $0.1 \mathrm{M}$ citric acid, $0.2 \mathrm{M} \mathrm{Na}_{2} \mathrm{HPO}_{4}$, $1 \mathrm{mM}$ EDTA, $0.15 \mathrm{M} \mathrm{NaCl}, 6 \mu \mathrm{g} / \mathrm{mL}$ acridine orange $\mathrm{pH} 6.0$ ). The stained samples were analyzed by flow cytometry exactly at $3 \mathrm{~min}$ after adding the acridine orange solution.

Samples were run through Cytomics FC500 (Beckman coulter, Inc. USA) as described above. Green fluorescence was detected using the FL-1 photodetector (530/28BP filter) and red fluorescence with the FL-3 photodetector (620SP filter). Data were collected from 10,000 events at 200 events/s for further analysis with Cell-Quest software (Becton Dickinson). At the beginning of each session, a standard semen sample was run through the cytometer, and settings were adjusted in order that mean fluorescence values (0-1023 linear scale) for FL-1 and FL-3 were 475 and 125 , respectively. Results of the DNA denaturation test were processed to obtain the ratio of red fluorescence to total intensity of the fluorescence (red/[red + green] $\times 100$ ), called DFI (DNA fragmentation index; formerly called $\alpha \mathrm{t}$ ) for each spermatozoa, representing the shift from green to red fluorescence. High values of DFI indicate chromatin abnormalities. Flow cytometry data was processed to obtain \%DFI (\% of spermatozoa with DFI > 25) and HDS (high DNA stainability: \% of spermatozoa with green fluorescence higher than channel 600, of 1024 channels).

\subsection{Statistical analysis}

The effects of post-mortem time on thawed sperm characteristics of the Spanish ibex were studied using general linear model (GLM-ANOVA), with pairwise comparisons performed using Bonferroni's correction. For this purpose, males ( $n=36$ ) were classified in three groups according to the postmortem time: less than $8 \mathrm{~h}, 8-12 \mathrm{~h}$ and more than $12 \mathrm{~h}$. Because we used epididymal spermatozoa, it was only possible to make single observations for each ibex. This analysis was conducted separately for each post-freezing evaluation time ( 0 and $2 \mathrm{~h}$ ) and for each incubation media (freezing diluent or modified Tyrode). The R statistical environmental (R Development Core Team, 2010) was used to perform the statistical analysis. Data are expressed as mean \pm S.E.M., unless otherwise stated.

\section{Results}

Sperm samples were obtained from 36 mature males. These males were divided in three groups. Samples of the first group of animals were taken within $8 \mathrm{~h}$ after animal death $(n=12)$ [\% motile sperm: $87.1 \pm 3.4$, \% viable sperm: $85.1 \pm 2.2, \%$ NAR: $87.8 \pm 2.8$ ], the second group were taken between 8 and $12 \mathrm{~h}(n=12)$ [\% motile sperm: $81.8 \pm 5.0$, \% viable sperm: $88.7 \pm 1.5$, \% NAR: $86.6 \pm 2.9$ ] and finally, the last group were taken having taken more than $12 \mathrm{~h}$ $(n=12)$ since animal death [\% motile sperm: $66.4 \pm 4.5$, \% viable sperm: $59.3 \pm 12.4$, \% NAR: $74.5 \pm 9.5$ ].

All parameters related to sperm motility decreased with post-mortem time (Table 1 ). The results showed significant differences $(P<0.05)$ among groups for most motility parameters evaluated immediately after thawing (Fig. 1), and after a 120 -min incubation at $37^{\circ} \mathrm{C}$ (Fig. 2). After freezing and thawing, when post-mortem time was longer than $12 \mathrm{~h}$, total motility was statistically different from the group of shorter than $8 \mathrm{~h}$ and the group of $8-12 \mathrm{~h}(P<0.001)$. The total motility, determined by CASA, decreased by more than a half when post-mortem time was higher than $12 \mathrm{~h}(40.55 \pm 9.36)$, compared with the group of less than $8 \mathrm{~h}(87.80 \pm 6.52)$. As expected, postmortem time caused dramatic changes in sperm motion kinematics, with spermatozoa changing to a less linear trajectory pattern [LIN (\%) $(<8 \mathrm{~h} v s>12 \mathrm{~h}): 52.68 \pm 1.45 v s$ $41.62 \pm 4.09)(P=0.025)]$ with lower velocities $[\mathrm{VAP}(\mu \mathrm{m} / \mathrm{s})$ $(<8 \mathrm{~h} v s>12 \mathrm{~h}): 78.16 \pm 4.31$ vs $48.63 \pm 6.77)(P<0.001)]$. Similar results were observed when spermatozoa were diluted in modified Tyrode (Fig. 3). However, after $2 \mathrm{~h}$ of incubation in the modified Tyrode (Fig. 4), the differences between treatments for the kinematic parameters disappeared and only the percentage of motile and progressive spermatozoa varied over time, decreasing as post-mortem time progressed (Fig. 4) with the exception of linearity.

Tables 1 and 2 summarized sperm motility and acrosome integrity assessed subjectively and sperm parameters assessed by flow cytometry. The percentage of viable spermatozoa was not affected by groups (Table 1 ). However, spermatozoa with normal acrosomes decreased over time, after thawing and after $2 \mathrm{~h}$ of incubation, becoming significant differences when it had spent more than $12 \mathrm{~h}$ since animal death (Table 1 ). The same effect was observed when samples were diluted in modified Tyrode (Table 2). Moreover, when spermatozoa had remained more than $12 \mathrm{~h}$ in testicles, the "apoptotic" like membrane changes population was statistically lower in both freezing media and in the Tyrode extender, after freezing and thawing than in the group of less than $8 \mathrm{~h}$ (Tables 1 and 2). After thawing, 
Table 1

Effects of post-mortem time on characteristics of cryopreserved epididymal Spanish ibex spermatozoa after thawing and after $2 \mathrm{~h}$ incubation at $37{ }^{\circ} \mathrm{C}$ in the freezing diluent.

\begin{tabular}{|c|c|c|c|}
\hline & \multicolumn{3}{|c|}{ Post-mortem time } \\
\hline & $<8 \mathrm{~h}$ & $8-12 \mathrm{~h}$ & $>12 \mathrm{~h}$ \\
\hline \multicolumn{4}{|l|}{ After freezing and thawing } \\
\hline Sperm motility $(\%)$ & $79.17 \pm 5.57^{\mathrm{a}}$ & $55.42 \pm 8.06^{\mathrm{b}}$ & $31.67 \pm 6.35^{\mathrm{c}}$ \\
\hline Acrosome integrity (\%) & $84.92 \pm 2.00^{\mathrm{a}}$ & $75.25 \pm 4.97^{a}$ & $56.92 \pm 7.94^{b}$ \\
\hline Viability (non-apoptotic) (\%) & $34.10 \pm 5.22$ & $31.98 \pm 4.97$ & $26.71 \pm 4.82$ \\
\hline Apoptotic-like membrane changes cells (\%) & $28.42 \pm 3.72^{\mathrm{a}}$ & $18.69 \pm 3.77^{\mathrm{a}, \mathrm{b}}$ & $14.25 \pm 3.26^{\mathrm{b}}$ \\
\hline Viable with intact plasmalemmna cells (\%) & $24.06 \pm 3.55$ & $26.29 \pm 4.19$ & $19.99 \pm 4.08$ \\
\hline Viable with high membrane phospholipid disorder cells (\%) & $11.28 \pm 3.22$ & $5.75 \pm 1.69$ & $7.74 \pm 1.96$ \\
\hline Viable with high $\Delta \psi_{\mathrm{m}}$ cells (\%) & $32.71 \pm 4.79$ & $29.97 \pm 5.11$ & $24.91 \pm 5.08$ \\
\hline \multicolumn{4}{|l|}{ After incubation for $2 \mathrm{~h}$ post-thawing } \\
\hline Sperm motility (\%) & $68.33 \pm 7.13^{\mathrm{a}}$ & $45.83 \pm 7.76^{b}$ & $21.00 \pm 4.89^{c}$ \\
\hline Acrosome integrity (\%) & $74.75 \pm 2.91^{\mathrm{a}}$ & $62.33 \pm 6.06^{\mathrm{a}}$ & $41.92 \pm 7.07^{\mathrm{b}}$ \\
\hline Viability (non-apoptotic) (\%) & $39.57 \pm 4.25$ & $28.70 \pm 4.04$ & $31.25 \pm 4.26$ \\
\hline Apoptotic-like membrane changes cells (\%) & $21.87 \pm 2.20^{\mathrm{a}}$ & $15.06 \pm 2.71^{\mathrm{a}, \mathrm{b}}$ & $12.33 \pm 3.52^{\mathrm{b}}$ \\
\hline Viable with intact plasmalemmna cells (\%) & $30.70 \pm 3.87$ & $24.52 \pm 4.17$ & $18.30 \pm 4.13$ \\
\hline Viable with high membrane phospholipid disorder cells (\%) & $10.23 \pm 3.22$ & $6.47 \pm 1.08$ & $9.15 \pm 2.54$ \\
\hline Viable with high $\Delta \psi_{\mathrm{m}}$ cells (\%) & $38.02 \pm 5.32^{\mathrm{a}}$ & $26.22 \pm 4.00^{\mathrm{a}, \mathrm{b}}$ & $21.81 \pm 4.39^{b}$ \\
\hline
\end{tabular}

* Sperm motility subjectively evaluated
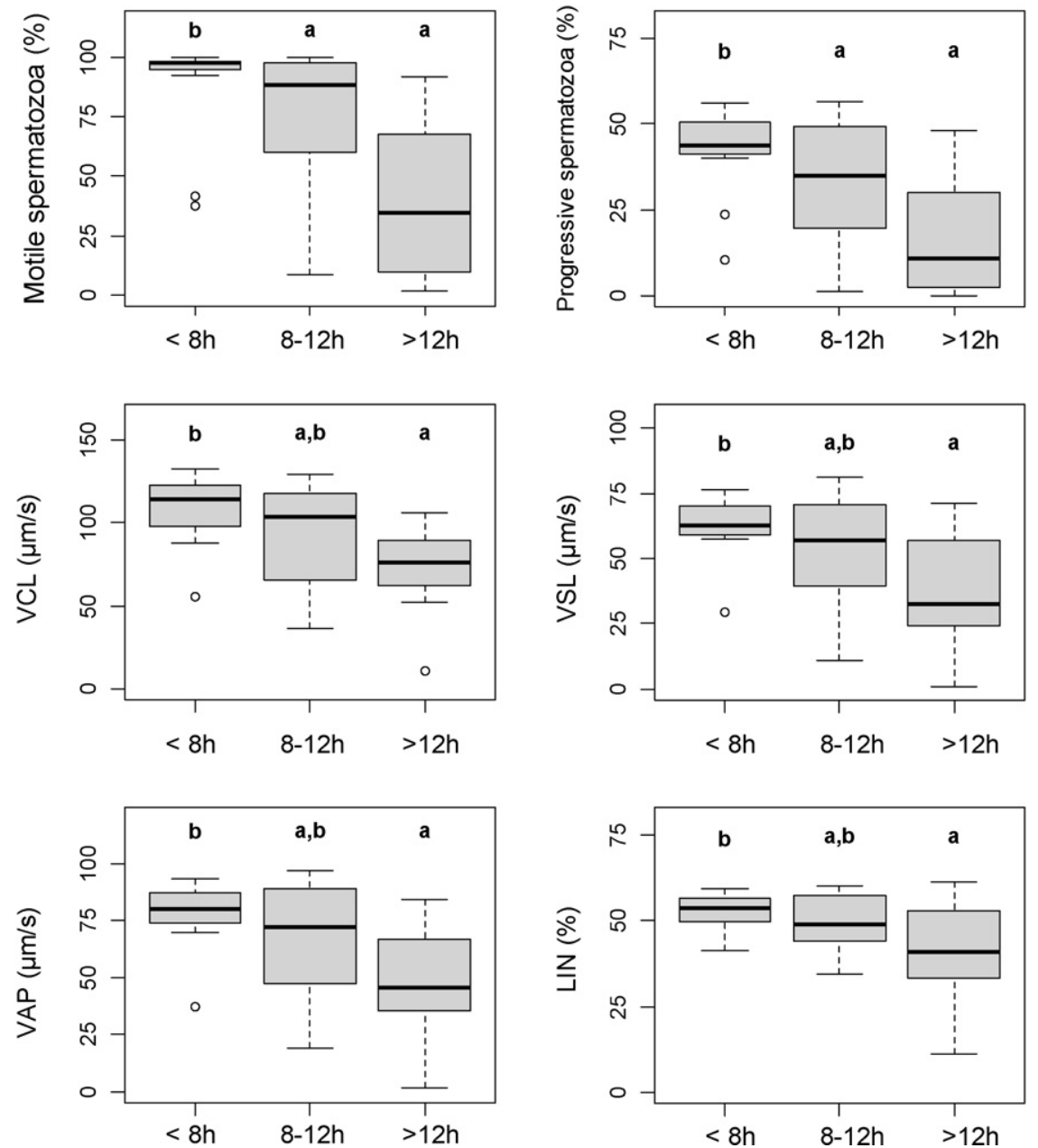

Fig. 1. Motility parameters of sperm samples diluted in the freezing diluent, assessed by CASA after thawing for the three groups (post-mortem time (< $8 \mathrm{~h} ; 8-12 \mathrm{~h}$ and $>12 \mathrm{~h}$ ). Different letters indicate significant differences $(P<0.05)$. The boxes spread form the 1 st to the 3rd quartiles, the whiskers extend to the interquartile range $\times 1.5$, and the horizontal line indicates the median. Outliers are represented by dots.) 

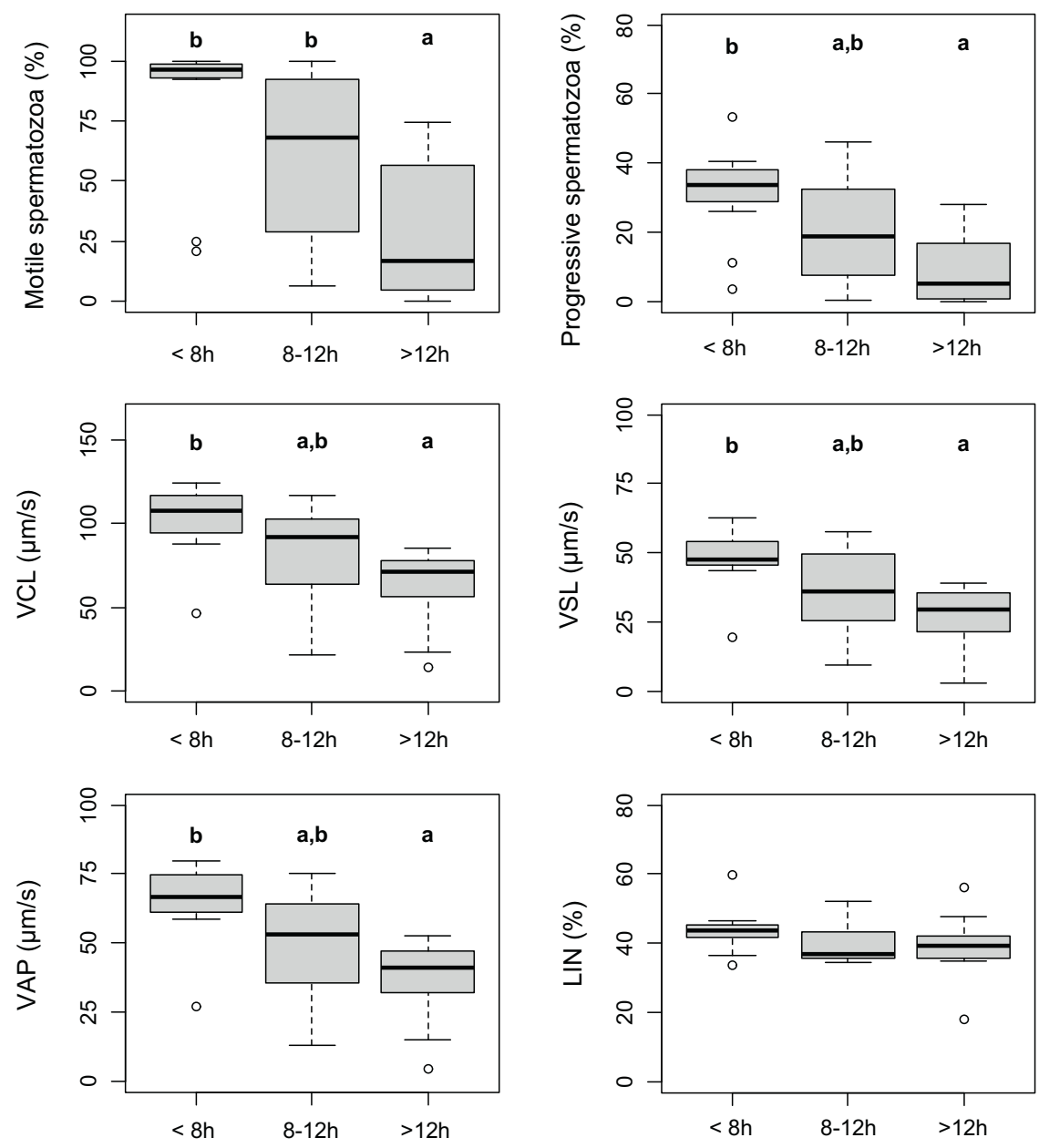

Fig. 2. Motility parameters of thawed sperm samples, assessed by CASA after $2 \mathrm{~h}$ of incubation in the freezing diluent $\left(37^{\circ} \mathrm{C}\right.$ ) for the three groups (postmortem time ( $<8 \mathrm{~h} ; 8-12 \mathrm{~h}$ and $>12 \mathrm{~h}$ ). Different letters indicate significant differences $(P<0.05)$. The boxes spread form the 1 st to the 3 rd quartiles, the whiskers extend to the interquartile range $\times 1.5$, and the horizontal line indicates the median. Outliers are represented by dots.)

M540/YOPRO-1 did not show any difference among groups of time after death (Table 1 ). After $2 \mathrm{~h}$ of incubation there were no significant differences $(P>0.05)$ in membrane phospholipid disorder among treatments. However, when samples were incubated in modified Tyrode during $2 \mathrm{~h}$, we could detect significant differences between post-mortem times (M540-/YOPRO-1-: live merocyanine-unstained cells < 8 h: $20.0 \pm 2.4 ; 8-12$ h: $14.3 \pm 2.5$; >12 h: $11.8 \pm 2.2$; Table 2), decreasing, after $12 \mathrm{~h}$, the percentage of live sperm cells with stable membrane. Moreover, the percentage of viable with high membrane phospholipid disorder cells decreased significantly when post-mortem time was more than $8 \mathrm{~h}(<8 \mathrm{~h}: 9.76 \pm 1.10 ; 8-12 \mathrm{~h}: 5.86 \pm 0.91 ;>12 \mathrm{~h}$ : $6.14 \pm 0.78)(P=0.01)$.

After $2 \mathrm{~h}$ of incubation in the freezing diluent, the percentage of thawed spermatozoa with high mitochondrial membrane potential was statistically $(P=0.04)$ higher the fewer hours had passed port-mortem (YOPRO1-/Mitotracker Deep red+: <8 h: $38.0 \pm 5.3$; 8-12 h: $26.2 \pm 4.0 ;>12$ h: $21.8 \pm 4.4$; Table 1 ).

We have evaluated the effect of post-mortem time on DNA integrity of Spanish ibex frozen-thawed spermatozoa. Table 3 summarizes SCSA results. There were no significant differences in chromatin stability among groups (post-mortem time), neither after freezing and thawing (SD-DFI: $2.9 \pm 0.4$; \%DFI: $6.9 \pm 1.8$; mean \pm SD), nor after $2 \mathrm{~h}$ of incubation at $37^{\circ} \mathrm{C}$ after thawing (SD-DFI: $3.2 \pm 0.3$; \%DFI: $7.1 \pm 1.1$; mean \pm SD). Moreover, we have also not found significant differences when samples were incubated in the modified Tyrode. Therefore, post-mortem time did not significantly affect chromatin stability after cryopreservation.

\section{Discussion}

Recently, Santiago-Moreno et al. (2007) evaluated the effect of post-mortem time on sperm parameters evaluated in vitro, and on the in vivo fertilization ability of thawed spermatozoa using heterologous fertilization intrauterine insemination in domestic goat (Capra hircus). The fertility obtained by heterologous artificial insemination was $19 \%$ and only goats inseminated with thawed spermatozoa recovered within $8 \mathrm{~h}$ after death became pregnant (Santiago-Moreno et al., 2006). The present study was 

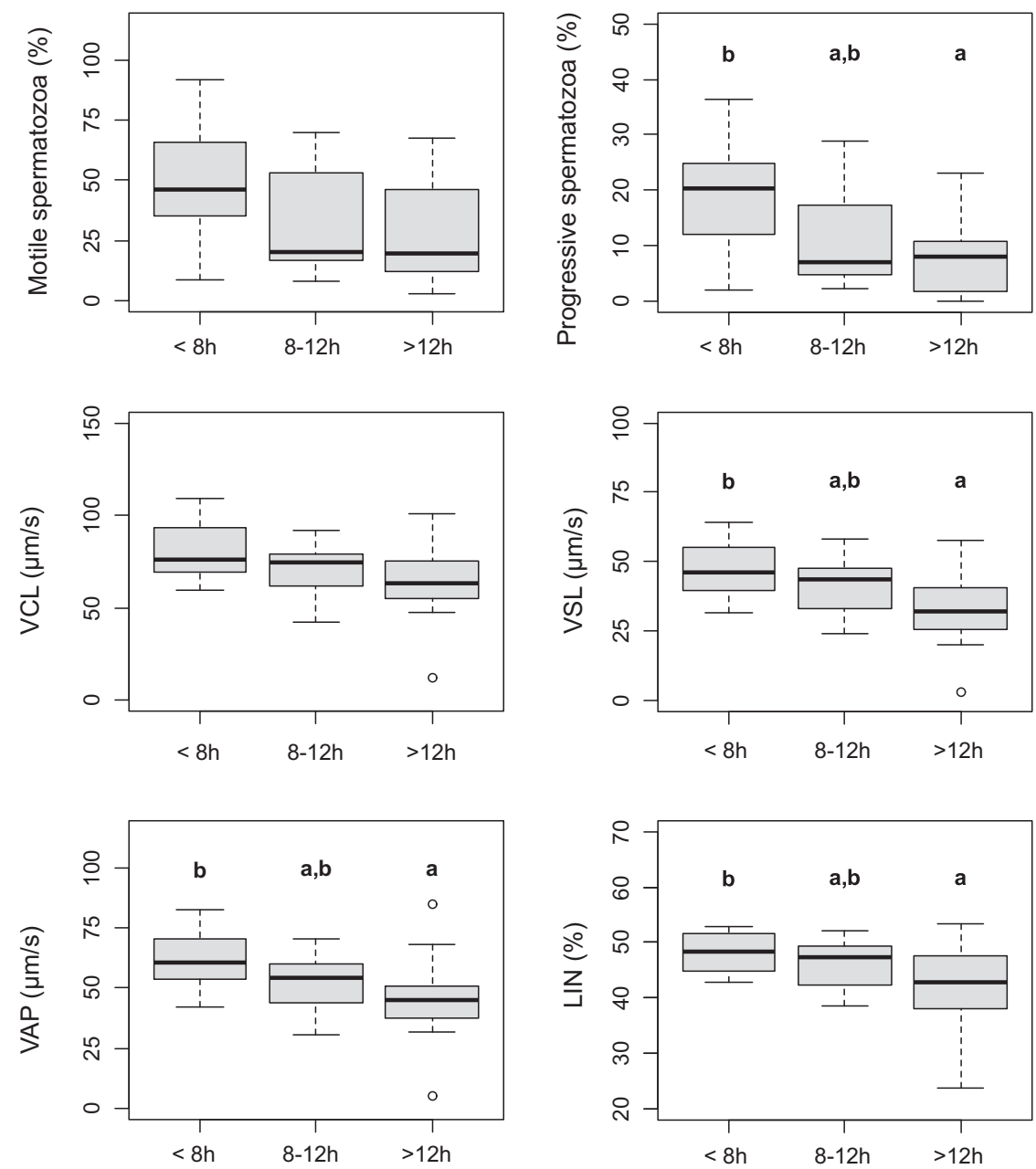

Fig. 3. Motility parameters of sperm samples diluted in modified Tyrode after thawing, assessed by CASA for the three groups (post-mortem time (<8 h; $8-12 \mathrm{~h}$ and $>12 \mathrm{~h}$ ). Different letters indicate significant differences $(P<0.05)$. The boxes spread form the 1 st to the $3 \mathrm{rd}$ quartiles, the whiskers extend to the interquartile range $\times 1.5$, and the horizontal line indicates the median. Outliers are represented by dots.)

designed to the more in depth knowledge of why only samples recovered within $8 \mathrm{~h}$ after death were able to produce offspring.Motility, directly related to mitochondrial activity, is commonly believed to be one of the most important characteristics associated with the fertilizing ability of sperm (Malo et al., 2005). In this study we have showed that the low fertility rates obtained after insemination with thawed semen of goats, found by Santiago-Moreno et al. (2006), may be due to problems in the kinematic patterns of spermatozoa motility. Our results, after incubating sperm in modified Tyrode (stressing treatment) indicate that motility is seriously compromised, decreasing to $20 \%$ when samples remained inside the cauda epidydimes more than $12 \mathrm{~h}$ prior to freezing. Moreover, motility evaluated by CASA showed that post-mortem time caused dramatic changes in sperm motion kinematics, with spermatozoa changing to a less linear trajectory pattern with lower velocities (VAP, VCL and VSL). This is an important finding since sperm velocity is one of the key features that have proved crucial in the process of fertilization in a large number of taxa (Holt et al., 1989; Gage et al., 2004). Moreover,
Malo et al. (2005) showed that differences in fertility rates between red deer males related strongly to three sperm swimming velocity parameters (VCL, VSL and VAP). We have found differences in those parameters not only after thawing and incubation but also under stressful conditions (incubation in modified Tyrode). In this regard, although, a priori, motility seems to be enough to fertilize the ovum, the fact that spermatozoa lose linearity and speed (VCL, VSL and VAP) can be a cause of low fertility. In this sense, our results agree with some studies in bull semen (Farrell et al., 1998; Amann et al., 2000; Kathiravan et al., 2008), showing that parameters like VCL, VSL and VAP can be use in predicting fertility. In this context, significant positive correlation between different velocity parameters and fertilization percentage has been reported in human spermatozoa (Fetterolf and Rogers, 1990).

Moreover, our results show that there is no significant difference in terms of live cells among the different post-mortem time, however, if we observe viability results (live, dead and the apoptotic-like membrane changes cells), more carefully, we can perceive that dead population 

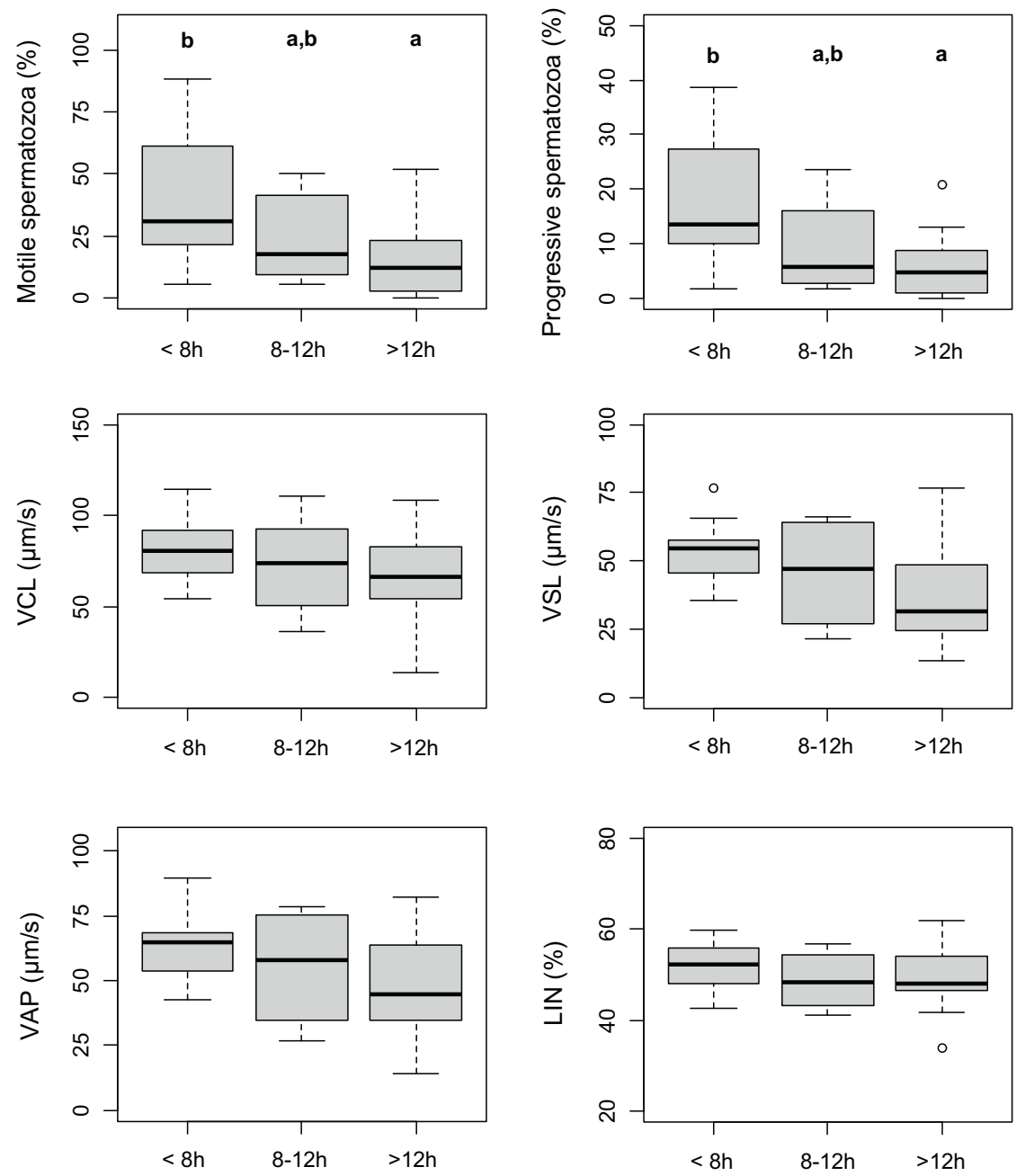

Fig. 4. Motility parameters of sperm samples diluted in modified Tyrode after thawing and after incubation during $2 \mathrm{~h}$ in the same diluent ( $37{ }^{\circ} \mathrm{C}$ ), assessed by CASA for the three groups (post-mortem time ( $<8 \mathrm{~h} ; 8-12 \mathrm{~h}$ and $>12 \mathrm{~h}$ ). Different letters indicate significant differences $(P<0.05$ ). The boxes spread form the 1 st to the 3rd quartiles, the whiskers extend to the interquartile range $\times 1.5$, and the horizontal line indicates the median. Outliers are represented by dots.)

always grows with post-mortem time, and that live population evolves just the opposite way. But if we observe at the percentages of "apoptotic" sperm cells, it gives us important information, because this percentage decreased over time, migrating to the dead population. Thus, we can see how sperm cells fall to apoptosis and inevitably to death with post-mortem time. In this regard, although the cauda epididymides of live animals provide an excellent environment for sperm storage, this event is not indefinite (Fernández-Santos et al., 2009b).

The presence of active mitochondria is important because they participate in many regulatory and maintenance processes. Mitochondria play a major role in the control of apoptosis (Rasola and Bernardi, 2007) containing some factors necessary to elicit it. In this context, our results also reveal that the post-mortem time has a direct effect on mitochondrial activity, as seen in our results after $2 \mathrm{~h}$ of incubation in the freezing diluent. In this regard, the loss of energy due to the decrease in active mitochondria could be responsible for the loss of maintenance of the membrane with a consequent increase in permeability (as shown in YO-PRO-1 and M540 results). In relation to this, the major function of mitochondria is supplying cellular energy, but the second major function is the regulation of cell death (Ott et al., 2007). Loss of $\Delta \psi_{\mathrm{m}}$ associated with apoptosis has been found previously in spermatozoa (Martin et al., 2005; Aziz et al., 2007; Grunewald et al., 2008; Martinez-Pastor et al., 2008). Our results are in agreement with those obtained by our own group in red deer (Martinez-Pastor et al., 2008), where it was proposed that the sequence of spermatozoon death would be: (1) loss of $\Delta \psi_{\mathrm{m}}$; (2) membrane changes (YOPRO-1+ and PI-); and (3) membrane damage (PI+). Intact spermatozoa with low $\Delta \psi_{\mathrm{m}}$ may be compromised cells. In this regard, again, we have demonstrated that lack of mitochondrial activity causes the emergence of apoptotic-like features in spermatozoa.In this regard, the loss of energy due to the decrease in active mitochondria, besides of 
Table 2

Effects of post-mortem time on characteristics of cryopreserved epididymal Spanish ibex spermatozoa after thawing and after $2 \mathrm{~h}$ of incubation at $37{ }^{\circ} \mathrm{C}$ in modified Tyrode.

\begin{tabular}{|c|c|c|c|}
\hline & \multicolumn{3}{|c|}{ Post-mortem time } \\
\hline & $<8 \mathrm{~h}$ & $8-12 \mathrm{~h}$ & $>12 \mathrm{~h}$ \\
\hline \multicolumn{4}{|l|}{ After freezing and thawing } \\
\hline Sperm motility $(\%)$ & $48.33 \pm 4.62^{\mathrm{a}}$ & $27.08 \pm 4.50^{\mathrm{b}}$ & $18.33 \pm 4.28^{\mathrm{b}}$ \\
\hline Acrosome integrity (\%) & $66.75 \pm 2.45^{\mathrm{a}}$ & $56.75 \pm 5.43^{\mathrm{a}}$ & $32.33 \pm 6.65^{b}$ \\
\hline Viability (non-apoptotic) (\%) & $22.94 \pm 3.20$ & $17.19 \pm 2.40$ & $18.20 \pm 3.82$ \\
\hline Apoptotic-like membrane changes cells (\%) & $29.67 \pm 4.76^{\mathrm{a}}$ & $17.34 \pm 4.50^{\mathrm{a}, \mathrm{b}}$ & $14.11 \pm 4.09^{b}$ \\
\hline Viable with intact plasmalemmna cells (\%) & $21.25 \pm 2.50$ & $14.21 \pm 2.13$ & $13.31 \pm 3.23$ \\
\hline Viable with high membrane phospholipid disorder cells (\%) & $6.85 \pm 1.32^{\mathrm{a}}$ & $5.67 \pm 0.78^{\mathrm{a}, \mathrm{b}}$ & $3.53 \pm 0.75^{\mathrm{b}}$ \\
\hline Viable with high $\Delta \psi_{\mathrm{m}}$ cells $(\%)$ & $21.17 \pm 2.98^{\mathrm{a}}$ & $13.73 \pm 2.01^{\mathrm{a}}$ & $13.87 \pm 3.24^{\mathrm{a}}$ \\
\hline \multicolumn{4}{|l|}{ After incubation for $2 \mathrm{~h}$ post-thawing } \\
\hline Sperm motility (\%) & $36.25 \pm 4.69^{\mathrm{a}}$ & $19.17 \pm 3.47^{b}$ & $14.17 \pm 3.25^{b}$ \\
\hline Acrosome integrity (\%) & $32.00 \pm 2.76^{\mathrm{a}}$ & $32.00 \pm 3.98^{\mathrm{a}}$ & $18.58 \pm 3.85^{b}$ \\
\hline Viability (non-apoptotic) (\%) & $25.22 \pm 2.88^{a}$ & $19.16 \pm 2.96^{\mathrm{a}, \mathrm{b}}$ & $16.07 \pm 2.28^{b}$ \\
\hline Apoptotic-like membrane changes cells (\%) & $26.47 \pm 3.55^{\mathrm{a}}$ & $17.90 \pm 3.89^{\mathrm{a}, \mathrm{b}}$ & $12.76 \pm 3.03^{b}$ \\
\hline Viable with intact plasmalemmna cells (\%) & $20.09 \pm 2.46^{\mathrm{a}}$ & $14.31 \pm 2.59^{\mathrm{a}, \mathrm{b}}$ & $11.79 \pm 2.25^{b}$ \\
\hline Viable with high membrane phospholipid disorder cells (\%) & $9.76 \pm 1.10^{\mathrm{a}}$ & $5.86 \pm 0.91^{\mathrm{b}}$ & $6.14 \pm 0.78^{b}$ \\
\hline Viable with high $\Delta \psi_{\mathrm{m}}$ cells $(\%)$ & $20.01 \pm 1.94^{\mathrm{a}}$ & $12.63 \pm 2.19^{b}$ & $11.53 \pm 2.06^{\mathrm{b}}$ \\
\hline
\end{tabular}

Sperm motility subjectively evaluated.

Table 3

Effects of post-mortem storage time on DNA integrity of cryopreserved epididymal Spanish ibex spermatozoa after thawing and after $2 \mathrm{~h}$ incubation at $37^{\circ} \mathrm{C}$ in the freezing diluent or in modified Tyrode.

\begin{tabular}{|c|c|c|c|}
\hline & \multicolumn{3}{|c|}{ Post-mortem time } \\
\hline & $<8 \mathrm{~h}$ & $8-12 \mathrm{~h}$ & $>12 \mathrm{~h}$ \\
\hline \multicolumn{4}{|c|}{ After freezing and thawing } \\
\hline SD-DFI & $2.93 \pm 0.43$ & $3.46 \pm 0.34$ & $2.66 \pm 0.34$ \\
\hline$\%$ DFI & $6.89 \pm 1.82$ & $5.54 \pm 1.13$ & $5.65 \pm 1.30$ \\
\hline $\operatorname{HDS}(\%)$ & $3.33 \pm 0.45$ & $4.15 \pm 0.64$ & $2.74 \pm 0.35$ \\
\hline \multicolumn{4}{|c|}{ After incubation for $2 \mathrm{~h}$ post-thawing in the freezing diluent } \\
\hline SD-DFI & $3.22 \pm 0.30$ & $3.32 \pm 0.35$ & $2.52 \pm 0.26$ \\
\hline$\%$ DFI & $7.11 \pm 1.14$ & $7.12 \pm 1.57$ & $7.26 \pm 1.62$ \\
\hline $\operatorname{HDS}(\%)$ & $2.93 \pm 0.48$ & $3.92 \pm 0.63$ & $3.30 \pm 0.54$ \\
\hline \multicolumn{4}{|c|}{ After incubation for $2 \mathrm{~h}$ post-thawing in modified Tyrode } \\
\hline SD-DFI & $2.65 \pm 0.22$ & $2.69 \pm 0.50$ & $2.54 \pm 0.42$ \\
\hline$\%$ DFI & $7.10 \pm 1.08$ & $6.55 \pm 1.26$ & $6.73 \pm 0.85$ \\
\hline HDS (\%) & $2.54 \pm 0.40$ & $3.32 \pm 0.33$ & $3.14 \pm 0.24$ \\
\hline
\end{tabular}

being responsible for the loss of maintenance of the membrane with a consequent increase in permeability, could be responsible for impaired kinematic parameters. For all the above, seems sensible to blame the problems of fertility among groups of post-mortem time, at least in part, to kinematic characteristics of sperm motility especially those related to its speed. If we consider all this information, differences in motility kinematic parameters could be due to a gradual loss of energy to create a correct move, straight and progressive, necessary for fertilization.

The results after dilution and incubation in modified Tyrode (stressing treatment) showed two important results. On one hand, in relation to the osmotic tolerance of spermatozoa to rapid removal of glycerol on thawing, our study showed that the one step decrease of glycerol by dilution with Tyrode medium resulted in a decline in sperm parameters, regardless of post-mortem time, compared to sperm parameters incubated in the freezing diluent. In this regard, dilution-incubation stress after the rapid removal of glycerol is related to differences in the relative permeability of glycerol and water across the sperm membrane (Gao et al., 1997). On the other hand, the test detected differences in sperm characteristics among post-mortem times. In this sense, our results showed that post-mortem time affects the percentages of spermatozoa with altered plasmalemma. Therefore, as post-mortem time increased, the damage at the plasma membrane, detected by the fluorchrome YO-PRO-1, was higher. In addition, membrane damage may occur secondary to rapid water movement across the membrane (Curry and Watson, 1994). In this regard, our results also show that the resistance of spermatozoa with different post-mortem time is reflected in the phospholipids disorder of plasma membrane (assessed by M540) increasing the percentage of viable with high membrane phospholipid disorder cells when post-mortem time was more than $8 \mathrm{~h}$. Moreover, as described above, after Tyrode dilution, motility is seriously compromised, decreasing to $20 \%$ when samples remained inside the cauda epidydimes more than $12 \mathrm{~h}$ prior to freezing. The difference in response subsequent to a return to isosmotic conditions may therefore reflect differences in the relative osmotic tolerances of sperm samples collected and frozen after different post-mortem times. Our results thus indicate that the spermatozoa with $>12 \mathrm{~h}$ post-mortem time, in addition to being the ones that worse resist the freezing process, are also those with a worse resistance to the osmotic shock caused by rapid removal of the glycerol. Therefore, differences in survival after cryopreservation among sperm samples with different post-mortem time agree well with their sensitivity to osmotic shock. The observation that tolerance to dilution-incubation stress is highly predictive of sperm survival after cryopreservation is important for two reasons, as described by Garde et al. (2003). First, it shows that differences in membrane structure, permeability, and elasticity influence the extent to which sperm will survive the cryopreservation process. Second, it suggests that 
sperm survival can be optimized by minimizing osmotic shock, perhaps by a gradual addition and removal of glycerol (Thomas and Garner, 1994).

Finally, the integrity of sperm DNA is another parameter that has tried to link with fertility results (Evenson and Jost, 2000; Januskauskas et al., 2001; Rybar et al., 2004; Kennedy et al., 2011). An optimal packing of DNA seems essential for high fertility potential (Spano et al., 2000), however, processes such as cryopreservation may impair the integrity of DNA (Peris et al., 2004). To our knowledge, no other researchers have investigated the DNA damage caused to the Spanish ibex epididymal spermatozoa by cryopreservation processes after different post-mortem time. We did not found any differences in DNA status among the different post-mortem times. This knowledge is of great importance since when a very valuable male dies and it is not possible to freeze the sperm quickly, although sperm characteristics such as the viability and motility decrease with the time elapsed since the death of the animal, as the DNA is intact, we have still the option of freezing the sample for trying in vitro fertilization (IVF) or intracytoplasmatic sperm injection (ICSI).

\section{Conclusions}

In conclusion, differences in fertility among postmortem times could be explain by an initial loss of $\Delta \psi_{\mathrm{m}}$, causing loss of a correct move, straight and progressive necessary for fertilization. Secondly, a series of membrane changes and finally, membrane damage, ultimately responsible for the death spermatozoa. Moreover, we conclude that post-mortem time could directly affect membrane structure, permeability, and elasticity influence the extent to which sperm will survive the cryopreservation process, as it shows the results obtained from the dilution-incubation test. Finally, one of the most important findings of this study is the demonstration that post-mortem time does not affect DNA integrity. In this regard, we have still the option of freezing the samples for trying IVF or ICSI, although post-mortem time affects the rest of sperm parameters.

\section{Acknowledgements}

This research was supported by MICINN grant AGL200801747. Miguel A. Coloma is the recipient of a predoctoral fellowship from the INIA. The authors would like to thank Sedella Council (Malaga) for their help in setting up the local laboratory, the gamekeepers of the National Game Reserve of the Tejeda and Almijara for obtaining the samples, the regional environmental council of Malaga (Consejería de Medio Ambiente, Junta de Andalucía) for their constant help in implementing the projects proposed.

\section{References}

Amann, R.P., Seidel Jr., G.E., Mortimer, R.G., 2000. Fertilizing potential in vitro of semen from young beef bulls containing a high or low percentage of sperm with a proximal droplet. Theriogenology 54 , 1499-1515.

Aziz, N., Said, T., Paasch, U., Agarwal, A., 2007. The relationship between human sperm apoptosis, morphology and the sperm deformity index. Hum. Reprod. 22, 1413-1419.

Comizzoli, P., Mermillod, P., Cognie, Y., Chai, N., Legendre, X., Mauge, R., 2001. Successful in vitro production of embryos in the red deer (Cervus elaphus) and the sika deer (Cervus nippon). Theriogenology 55, 649-659.

Curry, M.R., Watson, P.F., 1994. Osmotic effects on ram and human sperm membranes in relation to thawing injury. Cryobiology 31, 39-46.

Evenson, D.P., Jost, L., 2000. Sperm chromatin structure assay is useful for fertility assessment. Methods Cells Sci. 22 (2-3), 169-189.

Fandos, P., 1995. Factors affecting horn growth in male Spanish ibex (Capra pyrenaica). Mammalia 59, 229-235.

Farrell, P.B., Presicce, G.A., Brockett, C.C., Foote, R.H., 1998. Quantification of bull sperm characteristics measured by computer-assisted sperm analysis (CASA) and the relationship to fertility. Theriogenology 49 , 871-879.

Fernandez-Santos, M.R., Martinez-Pastor, F., Garcia-Macias, V., Esteso, M.C., Soler, A.J., Paz, P., Anel, L., Garde, J.J., 2007a. Sperm characteristics and DNA integrity of iberian red deer (Cervus elaphus hispanicus) epididymal spermatozoa frozen in the presence of enzymatic and nonenzymatic antioxidants. J. Androl. 28, 294-305.

Fernandez-Santos, M.R., Martinez-Pastor, F., Garcia-Macias, V., Esteso, M.C., Soler, A.J., de, P.P., Anel, L., Garde, J.J., 2007b. Extender osmolality and sugar supplementation exert a complex effect on the cryopreservation of Iberian red deer (Cervus elaphus hispanicus) epididymal spermatozoa. Theriogenology 67, 738-753.

Fernandez-Santos, M.R., Martinez-Pastor, F., Matias, D., DominguezRebolledo, A.E., Esteso, M.C., Montoro, V., Garde, J.J., 2009a. Effects of long-term chilled storage of red deer epididymides on DNA integrity and motility of thawed spermatozoa. Anim. Reprod. Sci. 111, 93-104.

Fernández-Santos, M.R., Domínguez-Rebolledo, A.E., Esteso, M.C., Garde, J.J., Martínez-Pastor, F., 2009b. Refrigerated storage of red deer epididymal spermatozoa in the epididymis diluted and with vitamin C supplementation. Reprod. Dom. Anim. 44 (2), 212-220.

Fetterolf, P.M., Rogers, B.J., 1990. Prediction of human sperm penetrating ability using computerized motion parameters. Mol. Reprod. Dev. 27, 326-331.

Friedmann, Y., Lubbe, K., Kilian, I., Grobler, D., Denniston, R., 2000. Changes in motility and morphological characteristics of African buffalo (Syncerus caffer) sperm during storage of the epididymis. Theriogenology 53, 332 (abstract).

Gage, M.J., Macfarlane, C.P., Yeates, S., Ward, R.G., Searle, J.B., Parker, G.A., 2004. Spermatozoal traits and sperm competition in Atlantic salmon: relative sperm velocity is the primary determinant of fertilization success. Curr. Biol. 14, 44-47.

Gao, d.Y., Mazur, P., Critser, J.K., 1997. Fundamental cryobiology of mammalian spermatozoa. In: Karow, A.M., Cristmer, J.K. (Eds.), Reproductive Tissue Banking: Scientific Principles. Academic Press, San Diego, pp. 263-328.

Garde, J.J., Perez, S., Ayllon, E., Garrido, D., Montoso, V., 1995. Live birth of hybrid $(O$. musimon $\times O$. aries) lambs following intrauterine insemination in domestic sheep with mouglon semen obtained $40 \mathrm{~h}$ postmortem. Theriogenology 218 (abstract).

Garde, J.J., Soler, A.J., Cassinello, J., Crespo, C., Malo, A.F., Espeso, G., Gomendio, M., Roldan, E.R.S., 2003. Sperm cryopreservation in three species of endangered gazelles (Gazella cuvieri, G. dama mhorr and G. dorcas neglecta). Biol. Reprod. 69, 602-611.

Garde, J., Martinez-Pastor, F., Gomendio, M., Malo, A., Soler, A., FernandezSantos, M., Esteso, M., Garcia, A., Anel, L., Roldan, E., 2006. The application of reproductive technologies to natural populations of red deer. Reprod. Domest. Anim. 41 (Suppl. 2), 93-102.

Gravance, C.G., Davis, R.O., 1995. Automated sperm morphometry analysis (ASMA) in the rabbit. J. Androl. 16, 88-93.

Grunewald, S., Said, T.M., Paasch, U., Glander, H.J., Agarwal, A., 2008. Relationship between sperm apoptosis signalling and oocyte penetration capacity. Int. J. Androl. 31, 325-330.

Harrison, R.A.P., Ashworth, P.J.C., miller, N.G.A., 1996. Bicarbonate $/ \mathrm{CO}_{2}$, an effector of capacitation, induces a rapid and reversibl change in the lipid architecture of boar sperm plasma membranes. Mol. Reprod. Dev. 45, 378-391.

Holt, W.V., Shenfield, F., Leonard, T., Hartman, T.D., North, R.D., Moore, H.D., 1989. The value of sperm swimming speed measurements in assessing the fertility of human frozen semen. Hum. Reprod. 4, 292-297. 
Januskauskas, A., Rodriguez-Martinez, H., 1995. Assessment of sperm viability by measurement of ATP, membrane integrity and motility in frozen/thawed bull semen. Acta Vet. Scand. 36, 571-574.

Januskauskas, A., Johannisson, A., Rodriguez-Martinez, H., 2001. Assessment of sperm quality through fluorometry and sperm chromatin structure assay in relation to field fertility of frozen-thawed semen from Swedish AI bulls. Theriogenology 55, 947-961.

Kardivel, G., Kumar, S., Kumaresan, a, Kathiravan, P., 2009. Capacitation status of fresh and frozen-thawed buffalo spermatozoa in relation to cholesterol level, membrane luidity and intracellular calcium. Anim. Reprod. Sci. 116, 244-253.

Kathiravan, P., Kalatharan, J., Edwin, M.J., Veerapandian, C., 2008. Computer automated motion analysis of crossbred bull spermatozoa and its relationship with in vitro fertility in zona-free hamster oocytes. Anim Reprod. Sci. 104, 9-17.

Kennedy, C., Ahlering, P., Rodriguez, H., Levy, S., Sutovsky, P., 2011. Sperm chromatin structure correlates with spontaneous abortion and multiple pregnancy rates in assisted reproduction. Reprod. Biomed. Online 22 (3), 272-276.

Kikuchi, K., Nagai, T., Kashiwazaki, N., Ikeda, H., Noguchi, J., Shimada, A., Soloy, E., Kaneko, H., 1998. Cryopreservation and ensuing in vitro fertilization ability of boar spermatozoa from epididymides stored at $4{ }^{\circ} \mathrm{C}$. Theriogenology 50, 615-623.

Killian, I., Bartels, P., Friedmann, Y., Denniston, R., Lubbe, K., 2000. Evaluating epididymal sperm of African wild ruminants: longevity when stored at $4{ }^{\circ} \mathrm{C}$ and viability following cryopreservation. Theriogenology 53, 336 (abstract).

Malo, A.F., Garde, J.J., Soler, A.J., Garcia, A.J., Gomendio, M., Roldan, E.R., 2005. Male fertility in natural populations of red deer is determined by sperm velocity and the proportion of normal spermatozoa. Biol. Reprod. 72, 822-829.

Martin, G., Sabido, O., Durand, P., Levy, R., 2005. Phosphatidylserine externalization in human sperm induced by calcium ionophore A23187: relationship with apoptosis, membrane scrambling and the acrosome reaction. Hum. Reprod. 20, 3459-3468.

Martínez-Pastor, F., Guerra, C., Kaabi, M., Diaz, A.R., Anel, E., Herraez, P., De Paz, P., Anel, L., 2005. Decay of sperm obtained from epididymes of wild ruminants depending on postmortem time. Theriogenology 63 , 24-40.

Martinez-Pastor, F., Fernandez-Santos, M.R., Del Olmo, E., DominguezRebolledo, A.E., Esteso, M.C., Montoro, V., Garde, J.J., 2008. Mitochondrial activity and forward scatter vary in necrotic, apoptotic and membrane-intact spermatozoan subpopulations. Reprod. Fertil. Dev. 20, 547-556.

Mortimer, S.T., 1997. A critical review of the physiological importance and analysis of sperm movement in mammals. Hum. Reprod. Update 3, 403-439.

Ott, M., Gogvadze, V., Orrenius, S., Zhivotovsky, B., 2007. Mitochondria, oxidative stress and cell death. Apoptosis 12, 913-922.
Peris, S.I., Morrier, A., Dufour, M., Bailey, J.L., 2004. Cryopreservation of ram semen facilitates sperm DNA damage: relationship between sperm andrological parameters and the sperm chromatin structure assay. J. Androl. 25, 224-233.

Pursel, V.G., Shulman, L.L., Jhonson, L.A., 1978. Distribution and morphology of fresh and frozen-thawed sperm in the reproductive tract of gilts after artificial insemination. Biol. Reprod. 19, 69-76.

Rasola, A., Bernardi, P., 2007. The mitochondrial permeability transition pore and its involvement in cell death and in disease pathogenesis. Apoptosis 12, 815-833.

Rodríguez-Martínez, H., Barth, A.D., 2007. In vitro evaluation of sperm quality related to in vivo function and fertility. Soc. Reprod. Fertil. Suppl. 64, 39-54.

Rybar, R., Faldikova, L., Machatkova, M., Rubes, J., 2004. Bull and boar sperm DNA integrity evaluated by sperm chromatin structure assay in the Czech Republic. Vet. Med. (Czech) 1, 1-8.

Sankai, T., Tsuchiya, H., Ogonuki, N., 2001. Short-term nonfrozen storage of mouse epididymal spermatozoa. Theriogenology 55, 1759-1768.

Santiago-Moreno, J., Toledano-Díaz, A., Pulido-Pastor, A., Gómez-Brunet, A., López-Bulnes, A., López-Sebastian, A., 2004. Post-thawing evaluation of Spanish ibex (Capra pyrenaica hispanica) epididymal spermatozoa recovered postmortem. Spanish J. Agric. Res. 2, 337-340.

Santiago-Moreno, J., Toledano-Diaz, A., Pulido-Pastor, A., Gomez-Brunet, A., Lopez-Sebastian, A., 2006. Birth of live Spanish ibex (Capra pyrenaica hispanica) derived from artificial insemination with epididymal spermatozoa retrieved after death. Theriogenology 66, 283-291.

Santiago-Moreno, J., Toledano-Diaz, A., Dorado, J., Pulido-Pastor, A., Coloma, M.A., Lopez-Sebastian, A., 2007. Recovery and cryopreservation of Spanish ibex epididymal spermatozoa. Arch. Androl. 53, 309-316.

Soler, A.J., Perez-Guzman, M.D., Garde, J.J., 2003a. Storage of red deer epididymides for four days at $5^{\circ} \mathrm{C}$ : effects on sperm motility, viability, and morphological integrity. J. Exp. Zoolog. A: Comp. Exp. Biol. 295, 188-199.

Soler, A.J., García, A.J., Fernández-Santos, M.R., Esteso, M.C., Garde, J.J., $2003 \mathrm{~b}$. Effects of thawing procedure on post-thawed in vitro viability and in vivo fertility of red deer epididymal spermatozoa cryopreserved at $-196^{\circ} \mathrm{C}$. J. Androl. 24, 746-756.

Spano, M., Bonde, J.P., Hjollund, H.I., Kolstad, H.A., Cordelli, E., Leter, G., 2000. Sperm chromatin damage impairs human fertility. The Danish First Pregnancy Planner Study Team. Fertil. Steril. 73, 43-50.

Thomas, C.A., Garner, D.L., 1994. Post-thaw bovine spermatozoal quality estimated from fresh samples. J. Androl. 15, 489-500.

Wildt, D.E., 2000. Genome resource banking for wildlife research, management, and conservation. ILAR J. 41, 228-234.

Yu, I., Leibo, S.P., 2002. Recovery of motile, membrane-intact spermatozoa from canine epididymides stored for 8 days at $4{ }^{\circ} \mathrm{C}$. Theriogenology 57 , 1179-2119. 